\title{
Estimating carbonate parameters from hydrographic data for the intermediate and deep waters of the Southern Hemisphere oceans
}

\author{
H. C. Bostock, S. E. Mikaloff Fletcher, and M. J. M. Williams \\ National Institute of Water and Atmospheric Research Ltd., Private Bag 14-901, Wellington, 6241, New Zealand \\ Correspondence to: H. C. Bostock (helen.bostock@niwa.co.nz)
}

Received: 31 January 2013 - Published in Biogeosciences Discuss.: 2 April 2013

Revised: 4 August 2013 - Accepted: 9 August 2013 - Published: 2 October 2013

\begin{abstract}
Using ocean carbon data from global datasets, we have developed several multiple linear regression (MLR) algorithms to estimate alkalinity and dissolved inorganic carbon (DIC) in the intermediate and deep waters of the Southern Hemisphere (south of $25^{\circ} \mathrm{S}$ ) from only hydrographic data (temperature, salinity and dissolved oxygen). A Monte Carlo experiment was used to identify a potential density $\left(\sigma_{\theta}\right)$ of 27.5 as an optimal break point between the two regimes with different MLR algorithms. The algorithms provide a good estimate of DIC $\left(R^{2}=0.98\right)$ and alkalinity $\left(R^{2}=0.91\right)$, and excellent agreement for aragonite and calcite saturation states $\left(R^{2}=0.99\right)$. Combining the algorithms with the CSIRO Atlas of Regional Seas (CARS), we have mapped the calcite saturation horizon (CSH) and aragonite saturation horizon (ASH) for the Southern Ocean at a spatial resolution of $0.5^{\circ}$. These maps are more detailed and more consistent with the oceanography than the previously gridded GLODAP data. The high-resolution ASH map reveals a dramatic circumpolar shoaling at the polar front. North of $40^{\circ} \mathrm{S}$ the $\mathrm{CSH}$ is deepest in the Atlantic $(\sim 4000 \mathrm{~m})$ and shallower in the Pacific Ocean $(\sim 2750 \mathrm{~m})$, while the CSH sits between 3200 and $3400 \mathrm{~m}$ in the Indian Ocean. The uptake of anthropogenic carbon by the ocean will alter the relationships between DIC and hydrographic data in the intermediate and deep waters over time. Thus continued sampling will be required, and the MLR algorithms will need to be adjusted in the future to account for these changes.
\end{abstract}

\section{Introduction}

Our understanding of the carbonate concentrations and saturation in the oceans has been considerably advanced by the collection of large global datasets such as GEOSECS (19601970s), World Ocean Circulation Experiment (WOCE, 1990s; Lamb et al., 2002; Key et al., 2004) and more recently CLIVAR/ $/ \mathrm{CO}_{2}$ Repeat Hydrography programme (2000s; Tanhua et al., 2008; Sabine et al., 2010). However, there are still large gaps, with many areas of the globe that have had little sampling for carbonate parameters. Some of these regions have significant topographic features, such as plateaux and ridges that produce complex currents. Thus extrapolation or gridding of global datasets across these regions does not provide meaningful local estimates. There may also be temporal variability in these parameters due to seasonal (Feely et al., 1988; Juranek et al., 2009, 2011; McNeil, 2010; McNeil et al., 2011; Alin et al., 2012) or interannual variations caused by phenomena like El Niño Southern Oscillation (ENSO; McNeil, 2010) or the Pacific Decadal Oscillation (PDO; Kim et al., 2010), which would not have been captured by the oneoff or decadal repeat transects across the global oceans.

In contrast, there are vast repositories of hydrographic data that have been compiled to produce ocean climatologies (e.g. World Ocean Atlas (WOA), 2009; CSIRO Atlas of Regional Seas (CARS), 2009). If it were possible to use the detailed hydrographic data to estimate the carbonate parameters in areas where there has been limited sampling for alkalinity and dissolved inorganic carbon (DIC), we could potentially provide detailed carbonate saturation estimates for all areas of the global ocean. This would allow more realistic values in 
areas where there are complex topography and currents that are not well represented by the interpolation of sparse carbon data.

One potential solution is to develop relationships between carbonate species and hydrographic data using a multiple linear regression (MLR) fit to the existing carbonate data, and then use these relationships and the more widely available oceanographic data to obtain high spatial and temporal resolution. This MLR approach was first used to predict carbonate species by Wallace (1995), based on observations that carbon exhibited strong correlations with other oceanographic parameters (Brewer et al., 1995). Over the last few years, several publications have used MLR techniques to estimate the carbonate parameters (or carbonate saturation), and changes in anthropogenic carbon uptake from hydrographic measurements (Archer, 1996; Brewer et al., 1997; Millero et al., 1998; Sabine et al., 1999; Lee et al., 2000, 2006; Wallace et al., 2001; McNeil et al., 2001; Friis et al., 2005; Sabine et al., 2008; Juranek et al., 2009, 2011; Kim et al., 2010; McNeil, 2010; Wanninkhof et al., 2010; Peng and Wanninkhof, 2010; Feely et al., 2012). Many of these studies have augmented the hydrographic data with nutrients and/or one of the carbon parameters, hence restricting the usability of these MLR algorithms to regions where these extra data also exist.

We focus on the intermediate and deep waters and the depth of the calcite (CSH) and aragonite saturation horizons (ASHs), as our interest is in understanding how carbonate ion concentrations of bottom waters, which interact with the seabed, affect the distribution of deep water carbonate organisms and sediments. For example, the global depth distribution of deep sea habitat-forming, aragonitic, stony (scleractinian) corals has been found to be controlled by the aragonite saturation state, with $95 \%$ of the organisms found above the ASH (Guinotte et al., 2006). With the ASH currently shoaling at $1-2 \mathrm{~m} \mathrm{yr}^{-1}$ in the Southern Hemisphere oceans (Feely et al., 2012), and predicted to shoal considerably in the Southern Ocean by 2100 (Orr et al., 2005; McNeil and Matear, 2008), this could significantly reduce the habitat for these benthic aragonitic organisms.

In this paper, we develop MLR algorithms to estimate carbonate parameters for intermediate and deep waters of the Southern Hemisphere, using hydrographic data (temperature, salinity and dissolved oxygen) and carbonate data (alkalinity and DIC) collected during the WOCE and CLIVAR campaigns from the Southern Ocean. After testing the MLR algorithms with the detailed CTD (conductivity, temperature, and and oxygen) data from the WOCE transects, we then apply the algorithms to the CARS (2009) climatology database to produce detailed maps of the $\mathrm{CSH}$ and ASH for the Southern Hemisphere oceans.



Fig. 1. Map of the Southern Hemisphere oceans with the major topographic features labelled, which are discussed in the text: SS Solomon Sea, SFB - South Fiji Basin, LHR - Lord Howe Rise, TB - Tasman Basin, KR - Kermadec Ridge, CR - Chatham Rise, CP - Campbell Plateau, WR - Walvis Ridge, NER - Ninety East Ridge, AAD - Australian-Antarctic Discordance. The main deep oceanographic flows into and out of the Southern Ocean are also illustrated with large arrows. North Atlantic Deep Water (NADW; orange), Indian Deep Water (IDW; orange), Pacific Deep Water (PDW; red) and Circumpolar Deep Water (CDW; white). The locations of the Southern Ocean fronts are also shown. Subantarctic Front (SAF; yellow dashed line) and Polar Front (PF; yellow dashed line) adapted from Sokolov and Rintoul (2009) and the full depth Antarctic Circumpolar Current (ACC; yellow arrows). The WOCE/CLIVAR stations used in this study are shown by the black dots, with the P16 transect, used in Figs. 2 and 4, highlighted in the middle of the South Pacific Basin.

\section{Oceanography}

The oceanography of the Southern Hemisphere oceans is dominated by the Southern Ocean (Orsi et al., 2005; Fig. 1). The Southern Ocean links all the large ocean basins of the world via the Antarctic Circumpolar Current (ACC), and acts as an important biogeochemical exchange venue, orchestrating the transfer of nutrients between deep and surface waters and the exchange of carbon between the ocean and atmosphere via the biological pump and direct sea-air exchange. The ACC homogenises the water masses south of the Subantarctic Front (SAF; Fig. 1), although there are subtle differences in the water chemistry at depth due to the influence of deep waters entering the Southern Ocean and the formation of intermediate waters that flow north into the adjacent Pacific, Atlantic and Indian basins. 
Subantarctic Mode Waters (SAMWs) and the low-salinity Antarctic Intermediate Waters (AAIWs) have high oxygen, as they are formed by the subduction of Antarctic Surface Waters (AASWs) at the SAF (Fig. 2; e.g. McCartney, 1977; 1982; Talley, 1996, 1999; Sloyan et al., 2010). The primary region of formation is the southeast Pacific, but there is subduction at several other locations in the Southern Ocean (Sallée et al., 2010; Bostock et al., 2013). These cool AASWs are subducted between potential density $\left(\sigma_{\theta}\right)$ surfaces of 26.9 and 27.3 and have low alkalinity and intermediate DIC (Gonzalez-Davila et al., 2011; Bostock et al., 2013; Fig. 2). The aragonite saturation horizon (ASH) sits at the base of the AAIW in most of the South Pacific Basin (Bostock et al., 2013).

Below the intermediate waters is the Circumpolar Deep Water (CDW). The CDW is commonly split into lower (1CDW, $\sigma_{\theta}>27.75$ ) and upper (uCDW, $\sigma_{\theta}=27.3$ to 27.75) components. The uCDW has a low-oxygen signature, with high alkalinity and DIC in the Pacific sector due to the influence of old Pacific Deep Water (PDW; Bostock et al., 2011; Fig. 2). These deep waters upwell at the polar front (PF; Fig. 2), where old carbon-rich waters release $\mathrm{CO}_{2}$ to the atmosphere. The ICDW also has high alkalinity and DIC (Fig. 2), but has higher salinity and oxygen than the overlying uCDW due to the influence of Antarctic Bottom Water (AABW) (Fig. 2; Orsi et al., 1999). CDW also has a large influence from North Atlantic Deep Water (NADW), especially in the South Atlantic, with its slightly higher salinity of 34.72-34.73 (Warren, 1981) and lower alkalinity and DIC (Gonzalez-Davila et al., 2011).

There is some variability in the intermediate and deep waters below the subtropical gyres in the different ocean basins. In the southeastern Pacific, there is significant upwelling in the Peru/Chile Current, which extends from $43^{\circ} \mathrm{S}$ to $10^{\circ} \mathrm{S}$. This results in the shoaling of the ASH to $<500 \mathrm{~m}$ (Feely et al., 2004; Bostock et al., 2013). These upwelled thermocline waters overlie the low salinity, well-oxygenated SAMW and AAIW, which recently formed in the southeast Pacific (McCartney, 1977).

The circulation in the southwest Pacific is complex due to the topography (Fig. 1). There are multiple types of AAIWs in the southwest Pacific (Tomczak and Godfrey, 1994; Hamilton, 2006; Bostock et al., 2013). Beneath the AAIW in the central South Pacific sits the highly corrosive PDW, with very high alkalinity and DIC, which causes the $\mathrm{CSH}$ to shoal to $2700 \mathrm{~m}$ between $130^{\circ} \mathrm{W}$ and $180^{\circ} \mathrm{W}$ (Bostock et al., 2011). These waters have excess alkalinity due to the dissolution of carbonate (Feely et al., 2002). The PDW is also the main water mass that enters the South Fiji Basin and other basins in the southwest Pacific, as the complex topography of this region blocks the flow from the south, and the only entrance is via the Solomon Sea (Fig. 1; Sokolov and Rintoul, 2000). In contrast, the Tasman Basin only receives CDW, with lower alkalinity and DIC, directly from the Southern Ocean. Therefore the deep waters in the Tas- man Basin have a deeper CSH at $\sim 3100 \mathrm{~m}$ (Bostock et al., 2011).

The AAIW flows into the South Atlantic along the western boundary under the Malvinas Current at 500-1200 m, but then continues north under the western boundary Brazil Current (Tomzcak and Godfrey, 1994). A tongue of uCDW lies immediately below the AAIW, but is only found as far north as $22^{\circ} \mathrm{S}$ (Stramma and England, 1999; Gonzalez-Davila et al., 2011). NADW, which has lower DIC and alkalinity than other deep waters, dominates the deep waters of the South Atlantic (Stramma and England, 1999). The NADW mainly flows down the southwest Atlantic, with smaller amounts in the southeast Atlantic (Stramma and England, 1999; Fig. 1). Below the NADW are a number of weak tendrils of northward flowing AABW, all of which are topographically constrained by seafloor features, especially in the southeast Atlantic where AABW is prevented from flowing north of $25^{\circ} \mathrm{S}$ by the Walvis Ridge (Tomzcak and Godfrey, 1994; Stramma and England, 1999; Fig. 1).

In the Indian Ocean the AAIW, with its conspicuous salinity and alkalinity minimum, overlies the Indian Deep Water (IDW). The IDW is characterised by a salinity maximum, intermediate alkalinity and DIC. These IDWs have been influenced by mixing with NADW, especially in the deep western boundary current (Ganachaud et al., 2000; Fig. 1). In the east, the CDW/AABW enters via the Australian-Antarctic Discordance and then moves north along the western boundary of the Ninety East Ridge (Tomczak and Godfrey, 1994; Fig. 1).

\section{Data}

This study uses all the WOCE and CLIVAR voyages for which both alkalinity and DIC were measured on bottle samples, and the associated hydrographic data were also collected (temperature, salinity, dissolved oxygen) (Table 1; Fig. 1). We used all the WOCE and CLIVAR data south of $25^{\circ} \mathrm{S}$, and deeper than $200 \mathrm{~m}$. This is motivated by the fact that intermediate and deep water masses formed in the Southern Ocean lie beneath the subtropical gyres. In total there are $\sim 20000$ bottle sample data for alkalinity and DIC. The sampling and analyses of the hydrographic and carbonate parameters were performed following standard WOCE protocols and using certified reference material (CRM; Dickson, 2001). The accuracy of the carbonate parameters is estimated at $\pm 3 \mu \mathrm{mol} \mathrm{kg}{ }^{-1}$ for DIC and $\pm 5 \mu \mathrm{mol} \mathrm{kg}-1$ for alkalinity (Lamb et al., 2002; Dickson et al., 2007). A secondary quality control was previously performed during the compilation of the GLODAP and later of the CARINA/PACIFICA databases by comparing the deep water $(>2000 \mathrm{~m}$ ) hydrographic, nutrient and carbonate data where they cross other transects, and most of the data are within measurement error (Key et al., 1996; 2002; Lamb et al., 2002; Sabine et al., 2010; Tanhua et al., 2010). We excluded one voyage 

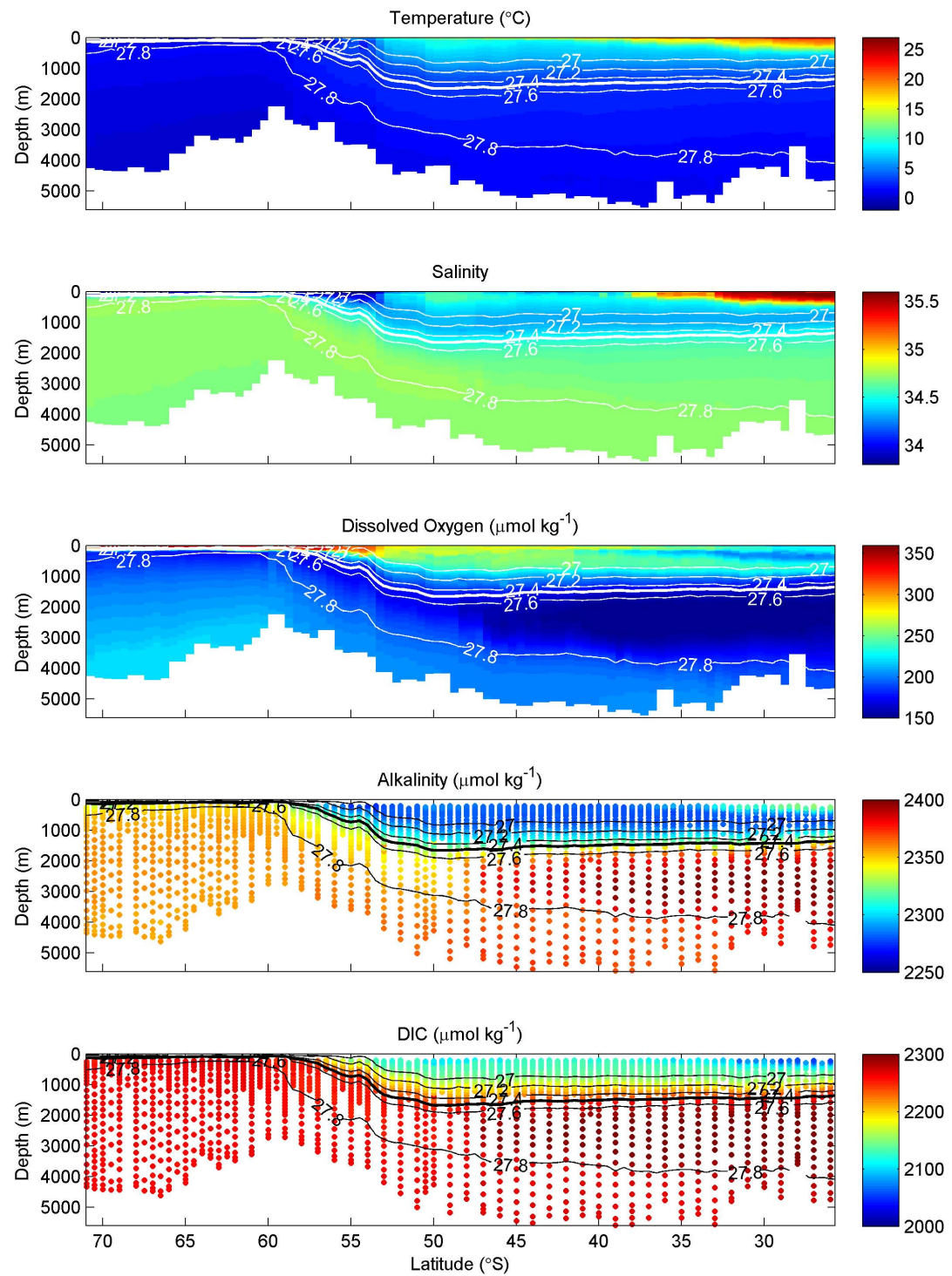

Fig. 2. P16 2005 measured data (see Fig. 1 for location). Temperature $\left({ }^{\circ} \mathrm{C}\right)$, salinity, dissolved oxygen $\left(\mu \mathrm{mol} \mathrm{kg}{ }^{-1}\right)$ from the CTD data with a vertical resolution of $2 \mathrm{~m}$. Alkalinity $\left(\mu \mathrm{mol} \mathrm{kg}{ }^{-1}\right)$ and dissolved inorganic carbon (DIC) ( $\left.\mu \mathrm{mol} \mathrm{kg}^{-1}\right)$ are measured on bottle samples. Overlain are the potential density $\left(\sigma_{\theta}\right)$ isopycnals with $\sigma_{\theta}=27.5$ highlighted in bold.

(P15S 1996) due to a larger offset in the alkalinity data $\left(-5 \mu \mathrm{mol} \mathrm{kg}^{-1}\right.$; Key et al., 2002).

We undertook a further quality control of the carbonate and hydrographic data from the WOCE and CLIVAR voyages using two approaches. First, any data that were larger or smaller than typical oceanographic values were removed (Table 2). Second, the data were then plotted against each other (e.g. temperature vs. salinity, DIC vs. oxygen). These were plotted against data of similar potential density to determine any obvious outliers greater than 3 standard deviations from the mean (Pearson, 2002). Outliers were not removed if there was a cluster of points from one voyage, or in one region, that could represent a real feature. For example, a cluster (24 data points) of very low oxygen samples exists immediately off- shore the west coast of South America on WOCE line P06E. This is an oxygen minimum zone; thus these data points represent a real oceanographic feature and have been retained in the dataset. In total $\sim 150$ samples $(<1 \%)$ were removed from the overall dataset of $\sim 20000$ data points. Most of the outliers were due to erroneous alkalinity and DIC measurements, but several were due to high-oxygen and high-salinity data.

The data were collected over two decades: the 1990s and 2000s. We found that there were subtle variations in the MLR algorithm coefficients when only the 1990s WOCE data are used compared to the 2000s CLIVAR data. This may be due to either the uptake of anthropogenic carbon or more likely the distribution of the datasets across the South- 
ern Hemisphere oceans. We have not made any corrections for the uptake of anthropogenic carbon in the intermediate and deep waters for this study. The anthropogenic signal is minor in the intermediate and deep waters, with only 5$10 \mu \mathrm{mol} \mathrm{kg}{ }^{-1}$ changes in DIC estimated between 200 and $1000 \mathrm{~m}$ (Sabine et al., 2008; Sallée et al., 2012). This is small relative to the combined uncertainty from the DIC measurements $\left( \pm 3 \mu \mathrm{mol} \mathrm{kg}{ }^{-1}\right)$ and the other sources of error in our algorithms. Furthermore, the spatial structure in our residuals from the algorithms does not appear to reflect anthropogenic carbon input, and any approach we might take to correct for the anthropogenic signal would introduce its own errors. The anthropogenic input of $\mathrm{CO}_{2}$ is not the focus of this paper.

Once we had developed and tested the algorithms using the WOCE/CLIVAR data, we applied them to the CSIRO Atlas of Regional Seas (CARS, 2009) climatology (Dunn and Ridgway, 2002; Ridgway et al., 2002). This database provides temperature, salinity and dissolved oxygen at a resolution of $0.5^{\circ}$, which have been subjected to consistent quality control and have been interpolated taking into account both bathymetry and land. CARS provides mean values and annual and semi-annual cycles, but does not provide information about temporal variability over longer timescales. The annual and semi-annual modes allow monthly climatological fields to be derived. In the Southern Ocean, research vessel logistics and operations have led to a summer bias in oceanographic measurements, so here we use only the CARS data temporally interpolated for January (austral summer).

\section{Approach}

In this approach, we treat the observed DIC and alkalinity (Alk) from the WOCE/CLIVAR cruises as a linear combination of temperature $(T)$, the salinity $(S)$, with a background salinity of 35 removed, oxygen $\left(\mathrm{O}_{2}\right)$ and a constant offset $(C)$ :

$\mathrm{DIC}=\alpha T+\beta(S-35)+\gamma \mathrm{O}_{2}+C$

$\mathrm{Alk}=\alpha T+\beta(S-35)+\gamma \mathrm{O}_{2}+C$,

where $T$ has units of ${ }^{\circ} \mathrm{C}$ and DIC, Alk, and $\mathrm{O}_{2}$ have units of $\mu \mathrm{mol} \mathrm{kg}{ }^{-1}$. Then, a singular value decomposition (SVD) is used to determine the best values of the parameters $\alpha, \beta, \gamma$, and $C$ to fit the observations.

Initially, this optimisation was undertaken with all of the data below the surface layer (depth $>200 \mathrm{~m}$ ). Analysis of the residuals (e.g. the difference between the modelled and observed values) as a function of potential density $\left(\sigma_{\theta}\right)$ revealed that there were likely to be two distinct regimes with different relationships between carbonate parameters and $T, S$, and $\mathrm{O}_{2}$. We were able to improve the fit substantially by dividing the data into two different density regimes and fitting them separately.

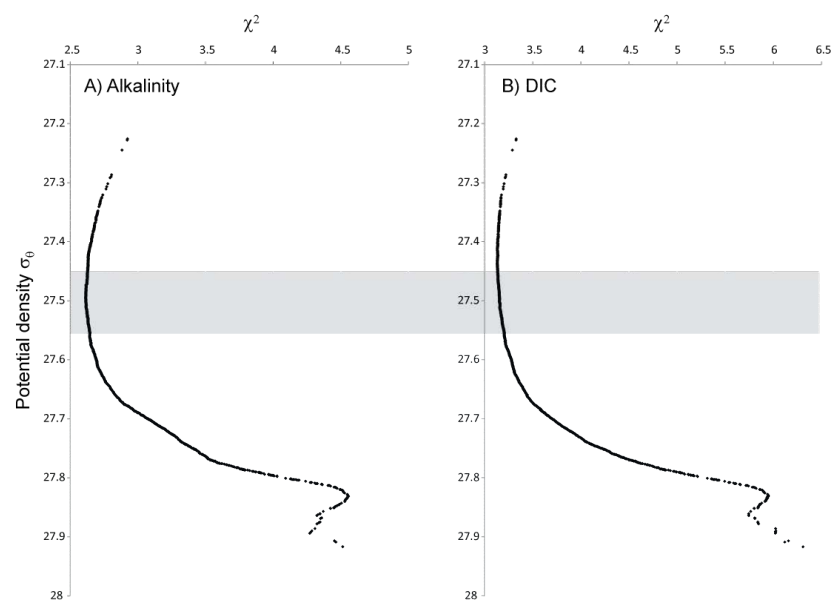

Fig. 3. Chi square $\left(\chi^{2}\right)$ of the best fit for all the data from the Monte Carlo (5000 iterations) run on potential density surfaces $\left(\sigma_{\theta}\right)$. (A) alkalinity data, (B) DIC data. $\sigma_{\theta}=27.5$ was chosen as the optimal breakpoint as it has a minimum $\chi^{2}$ for both alkalinity and DIC. The area shaded in grey is the overlap $\left(\sigma_{\theta}=27.5 \pm 0.05\right)$ where both algorithms are used and the value is averaged.

The optimal break point between the two regimes was determined objectively using a Monte Carlo simulation. We generated a random normal distribution of 5000 possible break points centred around $\sigma_{\theta}=27.6$ with a standard deviation of 0.1 and calculated the best fits to Eqs. (1) and (2) for each of these $5000 \sigma_{\theta}$ break points. Then, we evaluated the goodness of fit using the reduced $\chi^{2}$. The results of this Monte Carlo simulation show a clear, fairly flat minimum in the reduced $\chi^{2}$ over a $\sigma_{\theta}$ range of about 27.45 to 27.55 for alkalinity and 27.4 to 27.6 for DIC (Fig. 3). At $\sigma_{\theta}$ higher than 27.65 , the reduced $\chi^{2}$ begins to increase steeply.

For this analysis, we chose to use a break point of $\sigma_{\theta}=$ 27.5 throughout, because it represents a minimum reduced $\chi^{2}$ for both DIC and alkalinity. This also fits with the oceanography as it sits at the boundary between intermediate and deep waters. In order to avoid discontinuities at the density boundary between the two regimes when calculating values of DIC and alkalinity from these regressions, we take the mean of the two fits for data over the density range of $\sigma_{\theta}=27.45-27.55$.

The residual standard error (RSE) for the MLR fit is $\pm 7.3 \mu \mathrm{mol} \mathrm{kg}{ }^{-1}$ for DIC and $\pm 9.8 \mu \mathrm{mol} \mathrm{kg}{ }^{-1}$ for alkalinity, based on all the data used in the optimisation. In general, $70 \%$ of the DIC and alkalinity estimates are within 1 standard deviation of the data, and the $R^{2}$ of the measured versus estimated alkalinity and DIC was greater than 0.9 (Table 3 ).

The MLR picks out temperature and oxygen as the main controllers of DIC (Table 3). This is not surprising as DIC is affected by organic matter formation (or break down) in the water column which produces (or requires) oxygen. Lee et al. (2000) previously determined that surface DIC can be determined from temperature and nitrate (the latter closely 
Table 1. GLODAP/CLIVAR voyages used for this study.

\begin{tabular}{|c|c|c|c|}
\hline $\begin{array}{l}\text { WOCE } \\
\text { transect } \\
\text { number }\end{array}$ & Dates & Research ship & $\begin{array}{l}\text { Voyage leaders and } \\
\text { principal scientists } \\
\text { responsible for } \\
\text { carbon analyses }\end{array}$ \\
\hline \multicolumn{4}{|l|}{ Pacific } \\
\hline P15S 2001 & 24 May-8 June 2001 & RV Franklin & Wijffels, Tilbrook \\
\hline P14S 1996 & 05 Jan-10 Mar 1996 & RV Discoverer & Bullister, Feely \\
\hline P16S 2005 & 9 Jan-22 Feb 2005 & RV Revelle & Sloyan, Sabine \\
\hline P18 2008 & 15 Dec 2007-23 Feb 2008 & RV Ronald H. Brown & Bullister, Feely \\
\hline P18 1994 & 26 Jan-27 Apr 1994 & RV Discoverer & Feely \\
\hline P06 2003 & 3 Aug-16 Oct 2003 & RV Mirai & Fukasawa, Murata \\
\hline \multicolumn{4}{|l|}{ Southern } \\
\hline S04I 1996 & 3 May-4 July, 1996 & RV Nathaniel Palmer & Nowlin, Millero \\
\hline S04 1995 & 13 Dec 1994-02 Feb 1995 & RV Aurora Australis & Rintoul, Tilbrook \\
\hline SR03 2001 & 29 Oct-22 Nov 2001 & RV Aurora Australis & Rintoul, Tilbrook \\
\hline SR03 1995 & 13 Dec 1994-02 Feb 1995 & RV Aurora Australis & Rintoul, Tilbrook \\
\hline \multicolumn{4}{|l|}{ Indian } \\
\hline I06S 2008 & 5 Feb-8 Mar 2008 & RV Revelle & Speer, Feely \\
\hline I06S 1996 & 20 Feb-22 Mar 1996 & RV Marion Dufresne & Poisson \\
\hline I08 2007 & 4 Feb-17 Mar 2007 & $\mathrm{RV}$ Revelle & Swift, Feely \\
\hline I09 1995 & 1 Dec 1994-19 Jan 1995 & RV Knorr & McCartney, Wallace \\
\hline I08 1995 & 1 Dec 1994-19 Jan 1995 & RV Knorr & McCartney, Wallace \\
\hline I07 1995 & 19 Jun-20 Jul 1995 & RV Knorr & Talley, Wallace \\
\hline I05 1995 & 19 Jun-20 Jul 1995 & RV Knorr & Talley, Wallace \\
\hline I05 2002 & 10 Mar-16 Apr 1995 & RV Knorr & Talley, Winn \\
\hline \multicolumn{4}{|l|}{ Atlantic } \\
\hline A17 1995 & 4 Jan-22 Mar 1994 & RV Maurice Ewing & Memery, Wallace \\
\hline A16S 2005 & 11 Jan-26 Feb 2005 & RV Ronald H. Brown & Wanninkhof \\
\hline A10 2003 & 6 Nov-5 Dec 2003 & RV Mirai & Yoshikawa, Murata \\
\hline A10 1993 & 27 Dec-31 Jan 1993 & RV Meteor & Siedler, Wallace \\
\hline
\end{tabular}

Table 2. Initial quality control on the GLODAP and CLIVAR data.

\begin{tabular}{ll}
\hline Parameter & Data removed if \\
\hline Salinity & $<33.5$ or $>36$ \\
Oxygen & $>350 \mu \mathrm{mol} \mathrm{kg}$ \\
Alkalinity & $<$ DIC or $<2000$ or $>2600 \mu \mathrm{mol} \mathrm{kg}$ \\
DIC & $<1800$ or $>2500 \mu \mathrm{mol} \mathrm{kg}$ \\
\hline
\end{tabular}

related to oxygen in the oceans). The temperature factor may also be acting as a proxy for depth, with an increased $\alpha$ coefficient for deeper waters as oxygen decreases (Table 3). Alkalinity, on the other hand, is primarily influenced by salinity and temperature (Table 3; Millero et al., 1998; Lee et al., 2006). Alkalinity is also affected by carbonate dissolution and precipitation. Thus the measured $v$ estimated correlation for alkalinity $\left(R^{2}=0.91\right)$ is slightly lower than DIC $\left(R^{2}=0.98\right)$, as none of the parameters $(T, S$ or dissolved O) are directly affected by carbonate dissolution. Temperature and oxygen may be playing a proxy role in predicting depth, as the coefficients $\alpha$ and $\gamma$ increase for estimating alkalinity in the deep waters.

The largest residuals between the measured and estimated DIC and alkalinity are in the lower mixed layer/thermocline waters ( $\sigma_{\theta}=25.5$ to $26.5 ; 200-500 \mathrm{~m}$; Figs. 4 and 5$)$ and the deep waters $\left(\sigma_{\theta}=27.7\right.$ to $\left.28 ;>2500 \mathrm{~m}\right)$. While both DIC and alkalinity are over- and underestimated in the thermocline, the estimates for the deep waters are lower than the measured values. The high residuals are most commonly found in the PDW (1800-3500 $\mathrm{m}$ in P16S; Figs. 4 and 5). This is a region of excess alkalinity due to carbonate dissolution by these old corrosive PDWs (Feely et al., 2002). A separate algorithm could be developed for the PDW, but this was not undertaken as the water mass could not be defined by potential density. It would therefore have to be defined by oxygen content and another parameter, increasing the complexity and usefulness of this deliberately simple approach. 
Table 3. Coefficients and constants, residual standard error and $R^{2}$ for the MLR algorithms; see equations in text.

\begin{tabular}{|c|c|c|c|c|c|c|c|}
\hline \multirow[t]{2}{*}{ Depth } & \multirow[t]{2}{*}{ Parameter } & \multicolumn{4}{|c|}{$\begin{array}{c}\text { Coefficients for } T, S-35 \text {, } \\
\text { dissolved O respectively }\end{array}$} & \multirow[t]{2}{*}{ RSE } & \multirow[t]{2}{*}{$R^{2}$} \\
\hline & & $\alpha$ & B & $\gamma$ & Constant & & \\
\hline Intermediate & Alk & -7.418 & 96.957 & -0.079 & 2412.5 & 9.8 & 0.91 \\
\hline$\left(200 \mathrm{~m}\right.$ to $\left.<27.5 \pm 0.05 \sigma_{\theta}\right)$ & DIC & -14.866 & 53.682 & -0.569 & 2410.5 & 7.3 & 0.98 \\
\hline Deep & Alk & -17.027 & 100.25 & -0.663 & 2543.4 & 9.8 & 0.91 \\
\hline$\left(>27.5 \pm 0.05 \sigma_{\theta}\right)$ & DIC & -23.154 & 13.524 & -1.017 & 2493.6 & 7.3 & 0.98 \\
\hline
\end{tabular}

South of the PF, the MLR overestimates alkalinity and DIC considerably in the upper $1000 \mathrm{~m}$ and, to a lesser extent, down to $3000 \mathrm{~m}$ (Fig. 5). These very cold, dense waters are estimated by the deep alkalinity MLR algorithm as $\sigma_{\theta}>27.5$. This region adjacent to Antarctica is controlled primarily by the cold temperatures, and it appears that a separate MLR algorithm may be required for the region between the PF and Antarctica.

There are anomalous residuals in both DIC and alkalinity between $145^{\circ} \mathrm{W}$ and $180^{\circ} \mathrm{W}$ along P06 2003 (Fig. 4). This seems to be related to lower oxygen values along this section of the P06 transect. This is especially evident in the DIC (which is more affected by oxygen) with residuals throughout the water column, while the alkalinity residuals are only higher in the deeper waters (where oxygen plays a larger role in the MLR; Table 3). This highlights the requirement of using well-calibrated hydrographic data.

Previous researchers have used the MLR technique to determine aragonite saturation states directly (Juranek et al., 2009; Kim et al., 2010; Alin et al., 2012). Here we calculate the other carbonate parameters $\left(\left[\mathrm{CO}_{3}^{2-}\right]\right.$, aragonite, $\Omega$ calcite) using CO2sys software (Lewis and Wallace, 1998), the observed temperature, salinity, pressure, and estimated alkalinity and DIC from the algorithms. Silicate and phosphate were assumed to be 0 in the CO2sys as our aim was to use only the hydrographic data for this study. By assuming these nutrients are 0 , we find that the carbonate saturation states are overestimated by 1-3\%, with the highest differences for calcite, and at high latitudes of the Southern Ocean where silicate and phosphate are present in high concentrations. This gives a slightly deeper ASH (or CSH) than would be calculated if silicate and phosphate were included. The exact difference in the depth of the ASH (or CSH) will vary, dependent on the nutrient concentrations.

A comparison of the $\left[\mathrm{CO}_{3}^{2-}\right]$ calculated from the measured alkalinity and DIC with the estimated alkalinity and DIC gives an $R^{2}=0.96$ and RSE $= \pm 4 \mu \mathrm{mol} \mathrm{kg}-1$, while $\Omega$ aragonite and $\Omega$ calcite give an $R^{2}=0.99$ and $\mathrm{RSE}= \pm 0.05$ and \pm 0.08 , respectively (Fig. 6). This is just greater than the overall uncertainties of the aragonite and calcite saturation state calculations of \pm 0.03 and \pm 0.05 , respectively (Mucci, 1983; Millero, 1995; Feely et al., 2012). The high $R^{2}$ for $\Omega$ aragonite and $\Omega$ calcite suggests that the errors in the alkalinity and DIC are offset in the calculation of the saturation states. Thus the errors and high residuals in the DIC and alkalinity in the PDW do not significantly influence the final estimated depth of CSH.

\section{Application and discussion}

The development of the algorithm to determine alkalinity and DIC from hydrographic observations allows us to estimate the distribution of alkalinity and DIC at all locations where hydrographic data have been collected. We can utilise oceanographic climatologies to provide more extensive coverage of the ocean.

Alkalinity and DIC values south of $25^{\circ} \mathrm{S}$ were estimated from CARS temperature, salinity and dissolved oxygen. From these, $\Omega$ calcite and $\Omega$ aragonite were determined using the $\mathrm{CO} 2$ sys programme. This provided saturation states at each $0.5^{\circ}$ in latitude and longitude, and a vertical resolution of $250 \mathrm{~m}$ between 2000 and $5000 \mathrm{~m}, 100 \mathrm{~m}$ between 1000 and $2000 \mathrm{~m}$, and $10-50 \mathrm{~m}$ in the upper $1000 \mathrm{~m}$ of the water column. At each grid point in both latitude and longitude, the vertical profiles in $\Omega$ were linearly interpolated to determine the density where $\Omega=1$ (Fig. 7) and then the depth of the CSH and ASH (Fig. 8).

The CSH is at highest densities in the South Atlantic, where the NADW has high salinities, and in the cold, dense waters south of the PF (Fig. 7). The ASH also shows the highest densities in these regions, with a dramatic increase at the PF. The ASH generally sits at the base of the AAIW at $\sigma_{\theta}=27.3$, but sits at a higher density (and is much more variable) in the South Atlantic, probably due to mixing between the higher alkalinity, denser NADW and the lower alkalinity, less dense AAIW. The lowest density ASH is found off the west coast of South America due to the upwelling of the thermocline waters and the southward flow of EqPIW, an intermediate water which is made up of AAIW and upwelled PDW, the latter of which has high alkalinity and DIC (Bostock et al., 2010).

The depth of the CSH and ASH show similar patterns to previous global compilations (Feely et al., 2004), but have significantly more detail (Fig. 8a and b). The CSH and ASH 

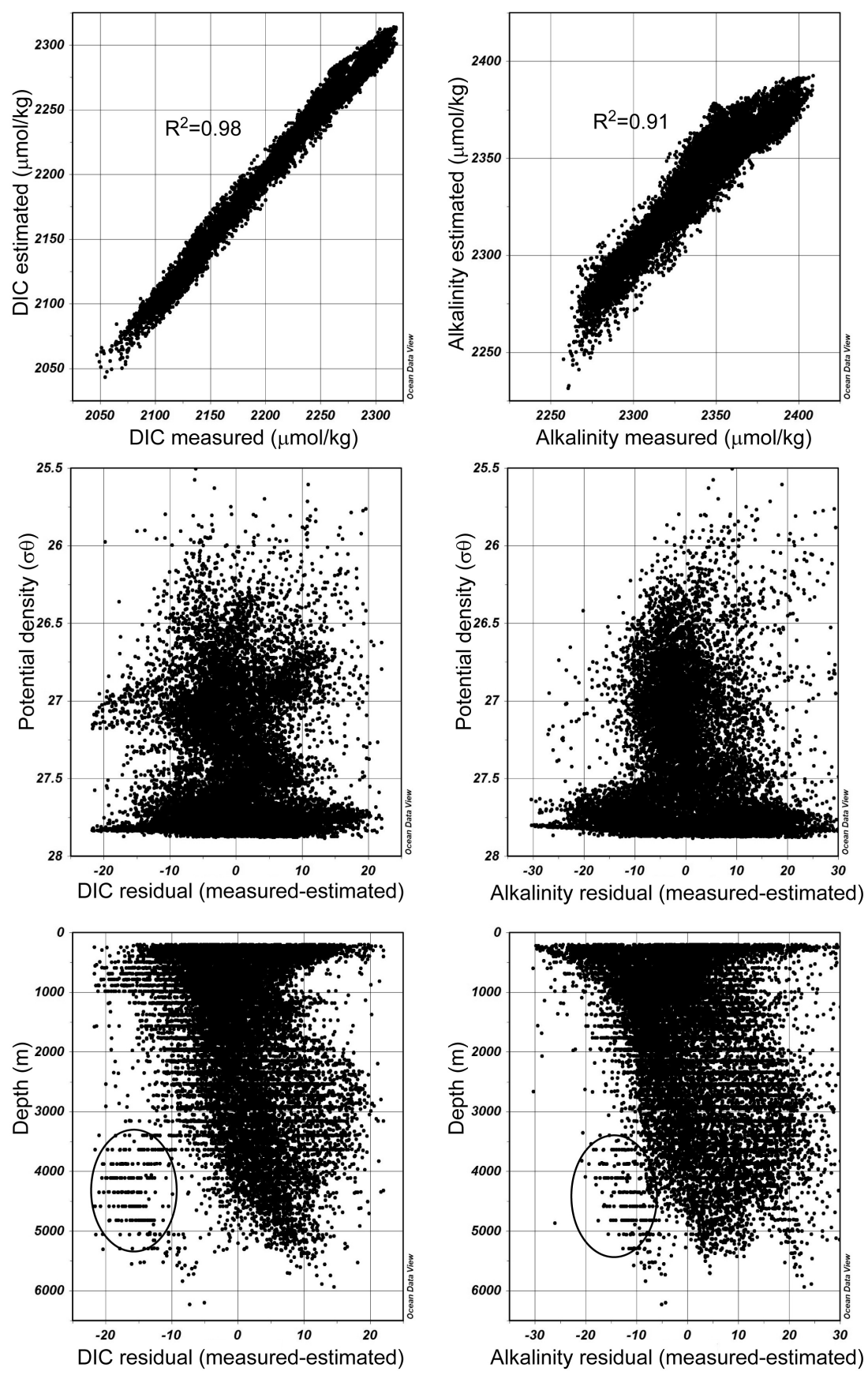

Fig. 4. Measured alkalinity and DIC versus estimated from the MLR algorithm for all data points deeper than $200 \mathrm{~m}$ and south of $25^{\circ} \mathrm{S}$. Residuals are plotted against potential density and water depth. The area in the circle is data from $\mathrm{P} 062003$ from $145^{\circ} \mathrm{W}$ to $180^{\circ} \mathrm{W}$ (see text for details).

maps derived from GLODAP gridded alkalinity and DIC data are shown for comparison. The GLODAP alkalinity and DIC data were supplemented with the temperature and salinity from CARS subsampled to the coarser (both vertical and horizontal) GLODAP grid, and the same procedure was followed to determine the depth where $\Omega=1$. For CSH, the coarser grid in the GLODAP data resulted in significant masking from the lower resolution bathymetry. The gridded GLODAP data appear to have been interpolated without taking into account bathymetry. This has created patterns in the $\mathrm{CSH}$ and ASH that are inconsistent with known ocean circulation. For example, there is evidence for a shoaling of the $\mathrm{CSH}$ in the eastern Tasman Sea (Fig. 8a) - a flow-over effect from the data in the main South Pacific Basin east of 

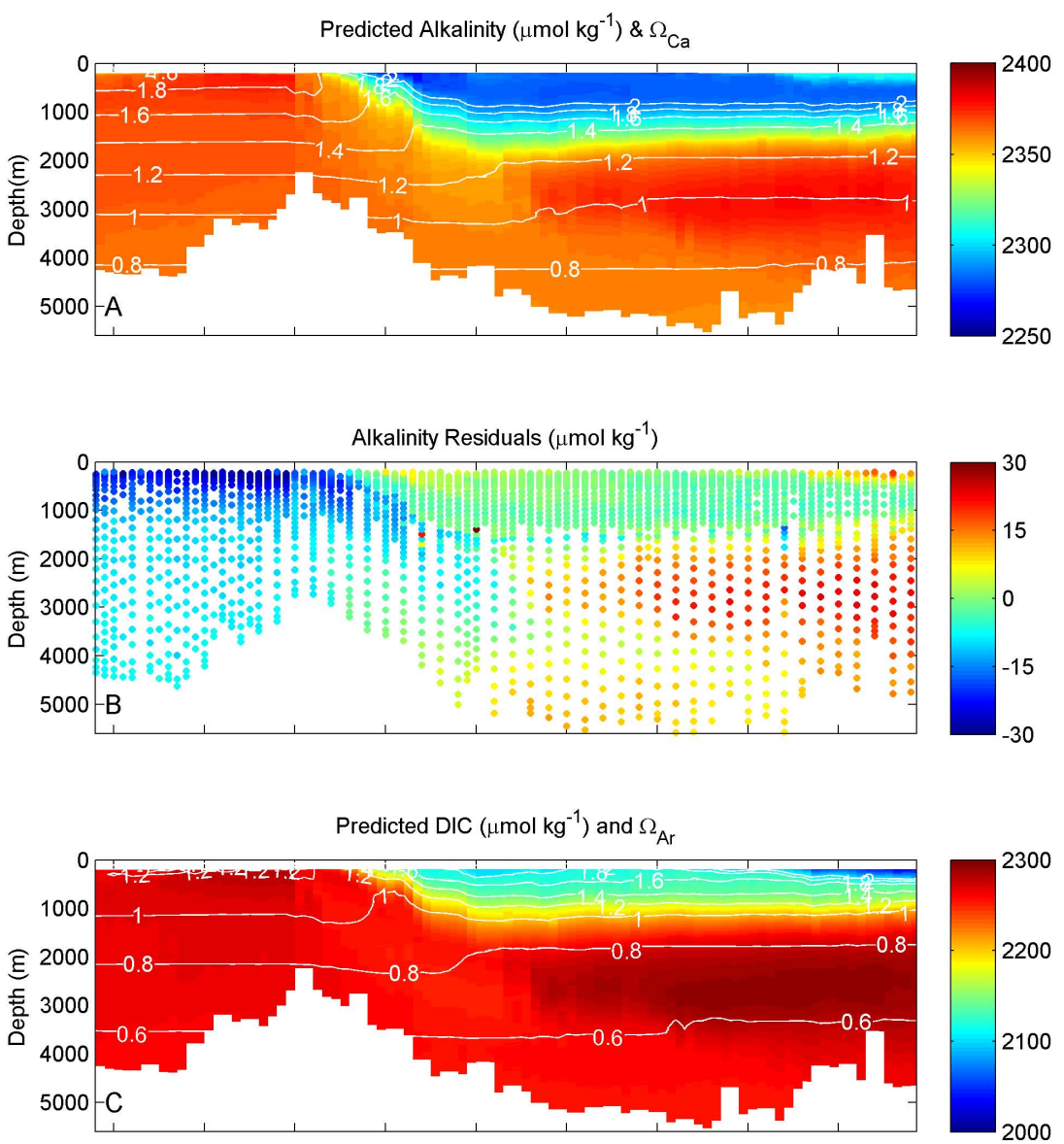

with letters.pdf

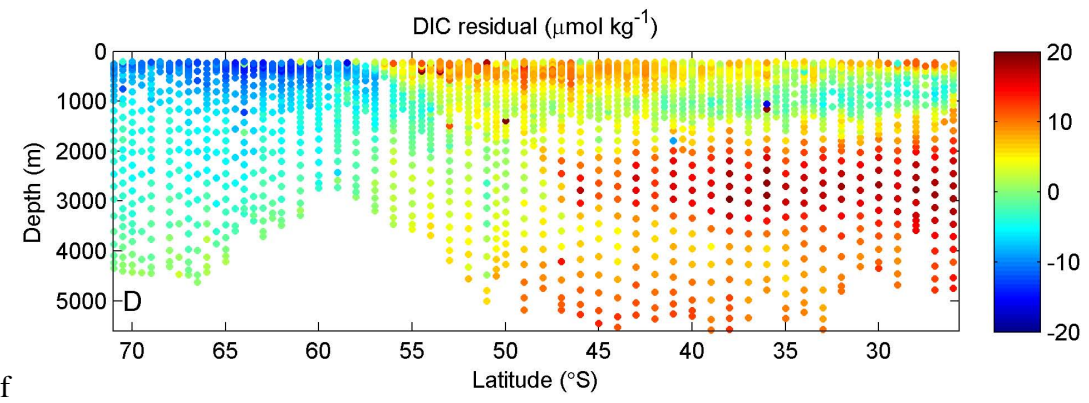

Fig. 5. P16S transect. Predicted alkalinity and DIC from the hydrographic data from CLIVAR transect P16 2005 using the MLR algorithms. (A) Alkalinity (with $\Omega$ calcite overlain), (B) residuals between (A) and the measured bottle data shown in Fig. 2, (C) DIC (with $\Omega$ aragonite overlain), (D) residuals between (C) and the measured bottle data shown in Fig. 2.

New Zealand - yet the only flow of deep waters into this basin is from the south due to the topographic highs such as Lord Howe Rise (Bostock et al., 2011). CARS, on the other hand, reduces distortion in the gridded fields by taking into account both bathymetry and land masses (Dunn and Ridgway, 2002). Thus we are able to derive maps of ASH and CSH that have higher resolution and are more consistent with the known oceanographic circulation.
South of $45^{\circ} \mathrm{S}$, the CSH in the Southern Ocean is fairly uniform around $3100-3400 \mathrm{~m}$ (Fig. 8a). There is a subtle deepening of the CSH between the SAF and the PF throughout the Southern Ocean. This is not an artefact of the CARS data, as it is also evident in the raw data from the individual transects (e.g. Fig. 6). This deepening of the CSH is coincident with a shoaling of the $\Omega$ calcite $=1.4$ to 1.6 , which suggests it is related to the physical oceanography; perhaps the upwelling of PDW at the PF also results in the minor depression of the $\mathrm{CSH}$. 


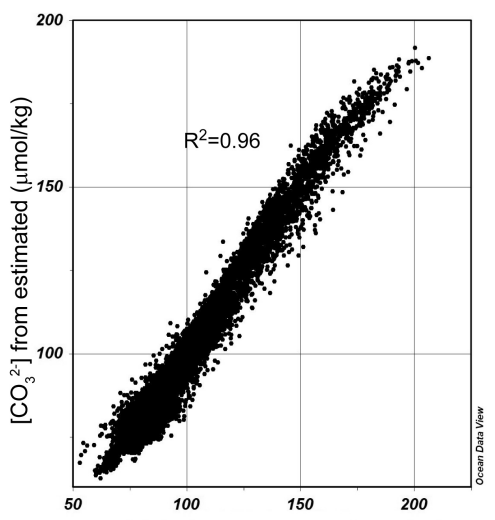

$\left[\mathrm{CO}_{3}{ }^{2-}\right]$ from measured $(\mu \mathrm{mol} / \mathrm{kg})$
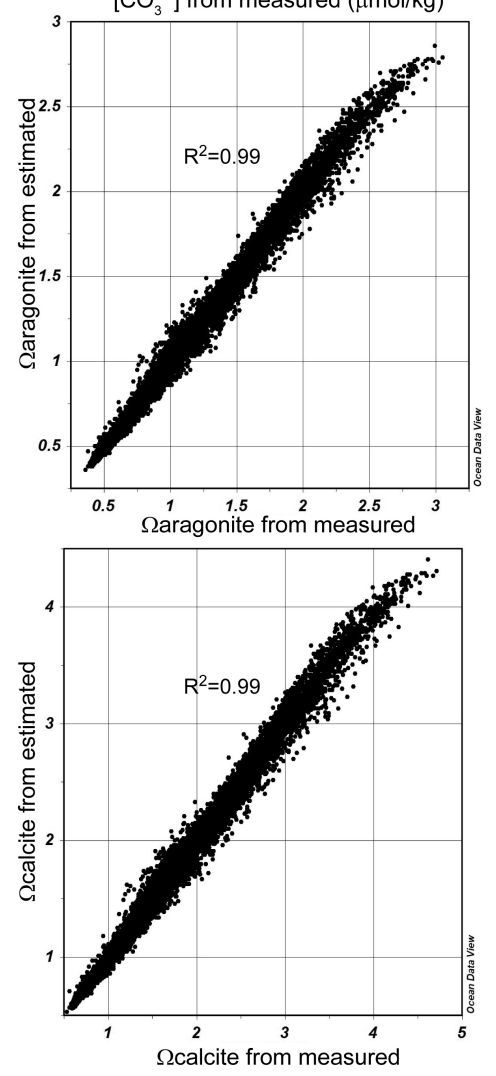

Fig. 6. Carbonate parameters $\left[\mathrm{CO}_{3}^{2-}\right], \Omega$ aragonite and $\Omega$ calcite calculated with CO2SYS (Lewis and Wallace, 1998), using measured versus estimated DIC and alkalinity.

The old corrosive PDW causes the CSH to be considerably shallower $(<3000 \mathrm{~m})$ in most of the South Pacific Basin (Fig. 8a). The influence of the PDW in the South Fiji Basin and other basins to the north of New Zealand is readily apparent, while the Tasman Sea has a deeper CSH as it is fed from the Southern Ocean by CDW, with no influence of PDW (Bostock et al., 2011). The deep western boundary current, which is predominantly made up of CDW and flows east of New Zealand around the Campbell Plateau, Chatham Rise and then north along the Kermadec Ridge (Fig. 1), is also ev- ident with a deepening of the CSH along its flow path compared to the rest of the South Pacific Basin (Fig. 8a).

The NADW influence is clearly shown with a deeper CSH $(>3500 \mathrm{~m})$ in the South Atlantic and in the western Indian Ocean, to the west of the Madagascar Ridge. The eastern Indian Ocean has the largest difference in the CSH between the interpolated GLODAP data and the estimates from the CARS climatology. The alkalinity data from GLODAP are patchy for this region, and thus the calculated $\mathrm{CSH}$ is highly variable, which is then interpolated across the ocean (Fig. 8a). In the eastern Indian Ocean, the deep waters are made up of $\mathrm{CDW}$, and therefore we would expect the depth of the CSH to be similar to that in the Southern Ocean.

The ASH depth estimated from the CARS dataset shows a significant shoaling between the SAF and the PF with the shallowest ASH at the PF due to the upwelling of corrosive uCDW. During January (austral summer), the ASH shoals to $<1000 \mathrm{~m}$ in the South Atlantic and Indian sectors of the Southern Ocean and to $<750 \mathrm{~m}$ water depth in the Pacific region of the Southern Ocean (Fig. 8b). This detail is not evident in the GLODAP interpolations (Fig. 8b; Feely et al., 2004). Similar to the GLODAP gridded data, the ASH is deeper, but highly variable in depth in the South Atlantic, probably due to the mixing of the NADW and the AAIW, while off the west coast of South America there is considerable shoaling of the ASH to $<500 \mathrm{~m}$ due to the upwelling.

With the potential routine deployment of dissolved oxygen sensors on future Argo floats, algorithms like these will allow routine determination of carbonate parameters from Argo floats (Juranek et al., 2011). This will provide higher spatial and temporal resolution of carbonate saturation estimates for the intermediate waters of the Southern Hemisphere oceans and allow the assessment of seasonal, interannual (Feely et al., 1988; Juranek, et al., 2009; McNeil et al., 2011; Alin et al., 2012), and decadal (Kim et al., 2010) variability. If future Argo floats also incorporate direct in situ carbonate measurements (Byrne and Yao, 2008), these algorithms could also be a useful tool to control quality of the data, although the relationship between DIC and the hydrographic parameters is likely to change over time (see discussion below).

While these MLR algorithms work well for estimating the alkalinity, DIC, $\left[\mathrm{CO}_{3}^{2-}\right], \Omega$ aragonite and $\Omega$ calcite for the intermediate and deep waters of the Southern Hemisphere open oceans, slight improvements can be made when the South Pacific, South Atlantic and Indian basin data are run separately, but this is beyond the scope of this paper.

The surface oceans and coastal zones are more complicated. Similar studies in the surface oceans (Millero et al., 1998; Lee et al., 2000, 2006; Sasse et al., 2013) and from the northeast Pacific (Oregon) (Juranek et al., 2009) and the Sea of Japan (Kim et al., 2010) have shown that separate, localised/regional algorithms are required. Thus more testing is needed to determine if the algorithms developed in this paper are useful in Southern Hemisphere marginal seas. South of the PF our MLR algorithms overestimate the alkalinity 
A

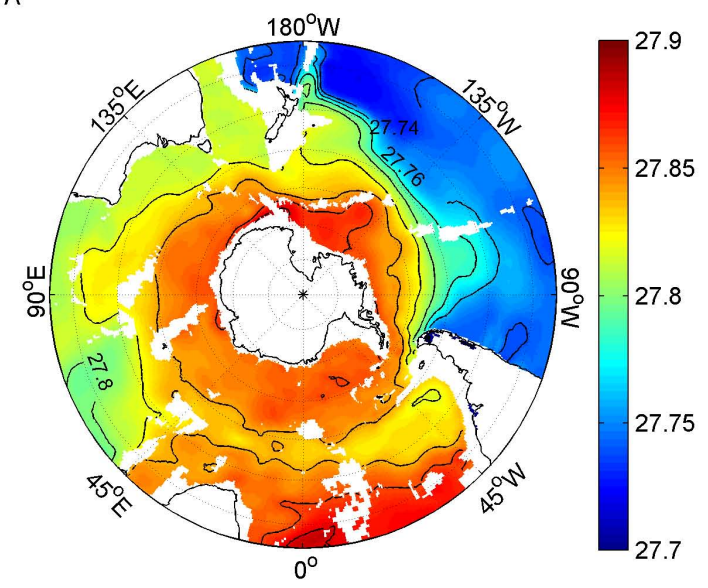

C

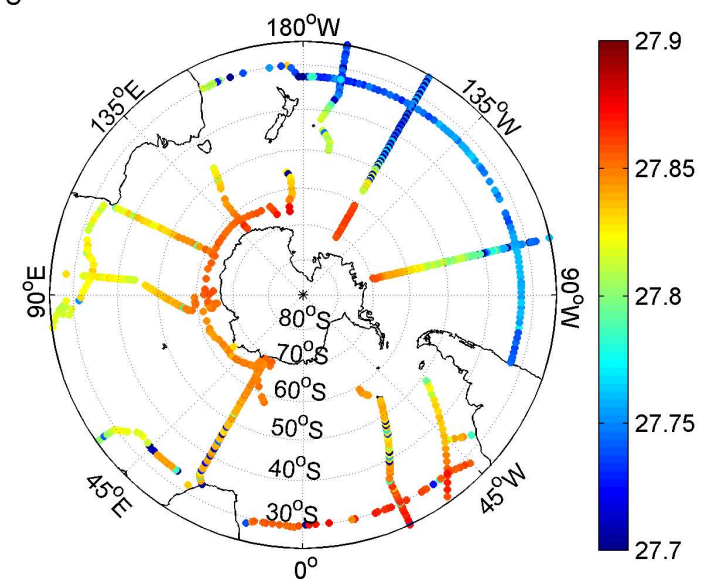

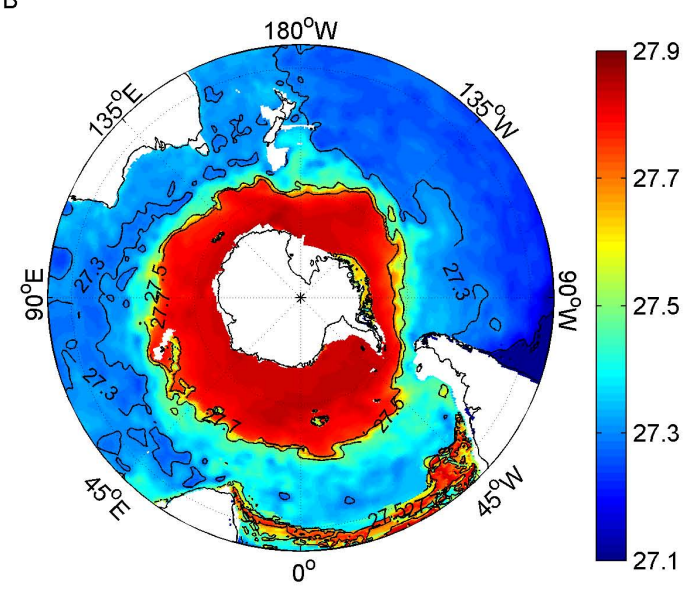

D

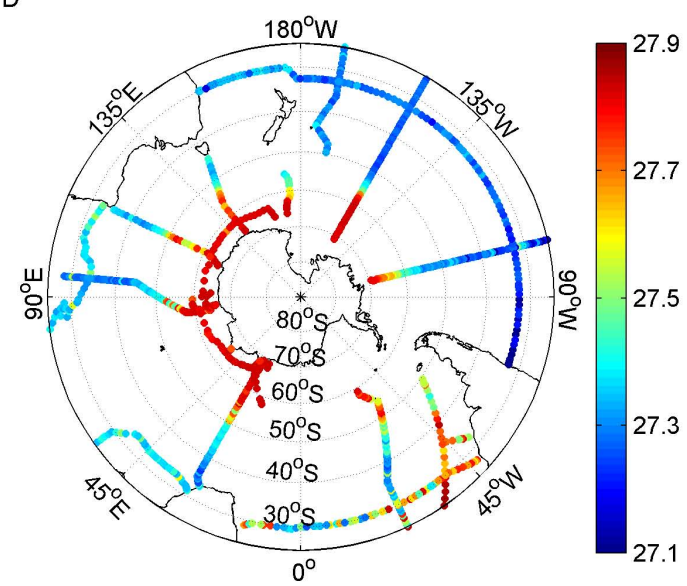

Fig. 7. Potential density of the (A) CSH (contours at $\sigma_{\theta}=0.02$ intervals) and (B) ASH (contours at $\sigma_{\theta}=0.2$ intervals) predicted from the CARS 2009 data (January). Potential density of (C) CSH and (D) ASH from the bottle data from GLODAP and CLIVAR.

and DIC in the upper $1000 \mathrm{~m}$ (Fig. 6), suggesting that waters around Antarctica may be sufficiently distinct as to benefit from a separate MLR routine.

While the focus of this paper has not been on the uptake of anthropogenic $\mathrm{CO}_{2}$ by the Southern Hemisphere oceans, the continued uptake will alter the relationship between DIC and alkalinity and hydrographic parameters over time, as demonstrated by McNeil et al. (2001). This is an especially important problem in the Southern Ocean, where the AASWs are taking up a large proportion of anthropogenic $\mathrm{CO}_{2}$. These waters then subduct to form AAIW, changing its carbonate chemistry, and storing large amounts of $\mathrm{CO}_{2}$ in AAIW (Sabine et al., 2004; Murata et al., 2007, 2008, 2010; Feely et al., 2012). Therefore MLR algorithms such as these, and other methods including neural networks (Velo et al., 2013; Sasse et al., 2013), do not abrogate the need for ongoing sampling to measure DIC and alkalinity directly. Direct measurements will be needed to determine changes in the MLR (a technique called extended MLR (eMLR)) resulting from the anthropogenic $\mathrm{CO}_{2}$ uptake (McNeil et al., 2001b; Peng et al., 2003; Friis et al., 2005; Sabine et al., 2008; Wanninkhof et al., 2010; Peng and Wanninkhof, 2010; Feely et al., 2012). However, these kinds of MLR methods give us the tools to maximise the value of direct measurements, by allowing meaningful extrapolation to larger areas. The algorithms also identify specific regions of interest, where processes can only be understood with dedicated sampling programmes.

\section{Conclusions}

Using the global carbonate datasets of WOCE (1990s) and CLIVAR (2000s), we have developed MLR algorithms to estimate the DIC, alkalinity, and saturation states of calcite and aragonite accurately for intermediate and deep waters of the Southern Hemisphere open oceans. When used in conjunction with the CARS (2009) climatology, this provides new detailed maps of the CSH and ASH which are oceanographically consistent. These will be used for future benthic habitat 

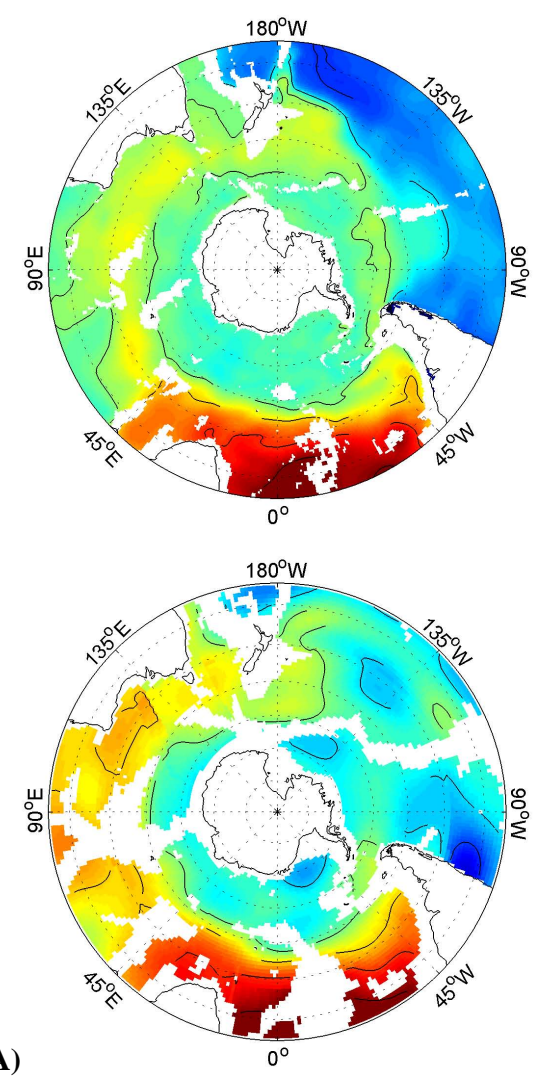
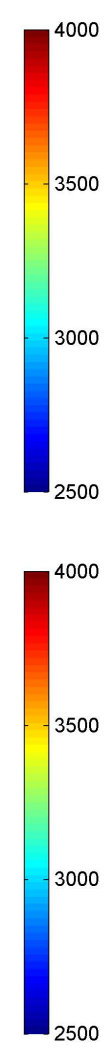

(B)

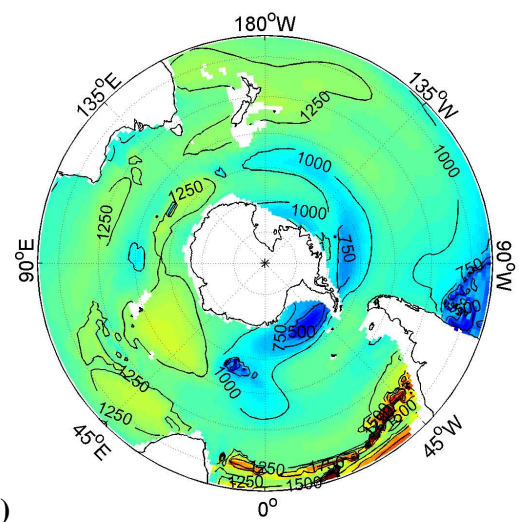

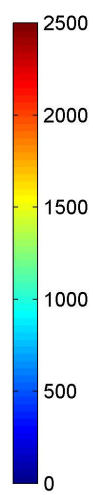

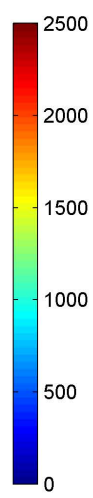

Fig. 8. (A) Depth of the CSH: the top figure is estimated from the CARS 2009 data (January), and bottom from GLODAP gridded data.(B) Depth of the ASH: the top is estimated from CARS 2009 data (January), bottom from the GLODAP gridded data. Contours are at $250 \mathrm{~m}$ intervals.

mapping and carbonate sediment models. With the deployment of oxygen sensors on Argo floats, these algorithms can be used to look at seasonal and interannual changes in the carbonate saturation states in the intermediate and deep waters.

There are larger residuals for the alkalinity and DIC estimates south of the PF, and further testing is required for marginal seas. These algorithms do not abolish the need for future sampling and measurement of DIC and alkalinity, as the coefficients of the MLR algorithms will change with future anthropogenic $\mathrm{CO}_{2}$ uptake by the oceans. They, however, may help to identify specific regions and depths of interest for targeted future sampling.
Acknowledgements. The authors would like to acknowledge all the funding agencies, voyage leaders and participants and that contributed to the global databases of WOCE and CLIVAR; these are an invaluable resource. Funding for this work has come from the New Zealand Ministries for Primary Industries (formerly the Ministry of Fisheries) (ZBD2010/41) and Business Innovation and Employment (CO1X1226) and NIWA as part of its government-funded core research. We would also like to thank the two anonymous reviewers and the editor for their constructive feedback on the manuscript.

Edited by: L. Bopp 


\section{References}

Alin, S. R., Feely, R. A., Dickson, A. G., Hernández-Ayón, J. M., Juranek, L. W., Ohman, M. D., and Goericke, R.: Robust empirical relationships for estimating the carbonate systemin the southern California Current System and application to CalCOFI hydrographic cruise data (2005-2011), J. Geophys. Res., 117, C05033, doi:10.1029/2011JC007511, 2012.

Archer, D. E.: An atlas of the distribution of calcium carbonate in sediments of the deep sea, Global Biogeochem. Cy., 10, 159174, 1996.

Bostock, H. C., Opdyke, B. N., Williams, M. J. M.: Characterising the intermediate depth waters of the Pacific Ocean using $\delta^{13} \mathrm{C}$ and other geochemical tracers, Deep-Sea Res. I, 57, 847-859, 2010.

Bostock, H. C., Hayward, B. W., Neil, H. L., Currie, K. I., and Dunbar, G. B.: Deep-water carbonate concentrations in the southwest Pacific, Deep Sea. Res. Deep-Sea Res., I, 58, 72-85, 2011.

Bostock, H. C., Sutton, P. J., Williams, M. J. M., and Opdyke B. N.: Reviewing the circulation and mixing of Antarctic Intermediate Water in the South Pacific using evidence from geochemical tracers and Argo float trajectories, Deep-Sea Res. I, 73, 84-98, 2013.

Brewer, P. G., Glover, D. M., Goyet, C., and Shafer, D. K.: The pH of the North Atlantic Ocean: Improvements to the global model for sound absorption in seawater, J. Geophys. Res., 100, 87618776, 1995

Brewer, P. G., Goyet, C., and Friederich, G.: Direct observation of the oceanic $\mathrm{CO}_{2}$ increase revisited, P. Natl. Acad. Sci. USA, 94, 8308-8313, 1997.

Byrne, R. H. and Yao, W.: Procedures for measurement of carbonate ion concentrations in seawater by direct spectrophotometric observations of $\mathrm{Pb}(\mathrm{II})$ complexation, Mar. Chem., 112, 128-135, 2008.

CARS: CSIRO Atlas of Regional Seas, available at: http://www. marine.csiro.au/ dunn/cars2009/ 2009.

Dickson, A. G.: Reference materials for oceanic $\mathrm{CO}_{2}$ measurements, Oceanography, 14, 21-22, 2001

Dickson, A. G., Sabine, C. L., and Christian J. R.: Guide to Best Practices for Ocean $\mathrm{CO}_{2}$ Measurements, PICES Spec. Publ., vol. 3, 191 pp., N. Pac. Mar. Sci. Organ., Sidney, B. C., Canada, 2007.

Dunn J. R. and Ridgway, K. R.: Mapping ocean properties in regions of complex topography, Deep Sea Res. I, 49, 591-604, 2002

Feely, R. A., Byrne, R. H., Acker, J. G., Betzer, P. R., Chen, C.-T. A., Gendron, J. F., and Lamb, M. F.: Winter-summer variations of calcite and aragonite saturation in the northeast Pacific, Mar. Chem., 25, 227-241, doi:10.1016/0304-4203(88)90052-7, 1988.

Feely, R. A., Sabine, C. L., Lee, K., Millero, F. J., Lamb, M. F., Greeley, D., Bullister, J. L., Key, R. M., Peng, T.-H., Kozyr, A., Ono, T., and Wong, C. S.: In situ calcium carbonate dissolution in the Pacific Ocean, Global Biogeochem. Cy., 16, 1144, doi:10.1029/2002GB001866, 2002.

Feely, R. A., Sabine, C. L., Lee, K., Berelson, W., Kleypas, J., Fabry, V. J., and Millero, F. J.: Impact of anthropogenic $\mathrm{CO}_{2}$ on the $\mathrm{CaCO}_{3}$ system in the oceans, Science, 305, 362-366, 2004.

Feely, R. A., Sabine, C. L., Byrne, R. H., Millero, F. J., Dickson, A. G., Wanninkhof, R., Murata, A., Miller, L. A., and Greeley, D.: Decadal changes in the aragonite and calcite saturation state of the Pacific Ocean, Global Biogeochem. Cy., 26, GB3001, doi:10.1029/2011GB004157, 2012.
Friis, K., Körtzinger, A., Pätsch, J., and Wallace, D. W. R. On the temporal increase of anthropogenic $\mathrm{CO}_{2}$ in the subpolar North Atlantic, Deep Sea Res., I, 52, 681-698, doi:10.1016/j.dsr.2004.11.017, 2005.

Ganachaud, A., Wunch, C., Marotzke, J., and Toole, J.: Meridional overturning and large-scale circulation of the Indian Ocean, J. Geophys Res., 105, 26117-26134, 2000.

González-Dávila, M., Santana-Casiano, J. M., Fine, R. A., Happell, J., Delille, B., and Speich, S.: Carbonate system in the water masses of the Southeast Atlantic sector of the Southern Ocean during February and March 2008, Biogeosciences, 8, 14011413, doi:10.5194/bg-8-1401-2011, 2011

Guinotte, J. M., Orr, J., Cairns, S., Freiwald, A., Morgan, L., and George, R.: Will human-induced changes in seawater chemistry alter the distribution of deep-sea scleractinian corals?, Front. Ecol. Environ., 4, 141-146, 2006.

Hamilton, L. J.: Structure of the Subtropical Front in the Tasman Sea, Deep-Sea Res., I, 53, 1989-2009, 2006.

Juranek, L. W., Feely, R. A., Peterson, W. T., Alin, S. R., Hales, B., Lee, K., Sabine, C. L., and Peterson, J.: A novel method for determination of aragonite saturation state on the continental shelf of central Oregon using multi-parameter relationships with hydrographic data, Geophys. Res. Lett., 36, L24601, doi:10.1029/2009GL040778, 2009.

Juranek, L. W., Feely, R. A., Gilbert, D., Freeland, H., and Miller, L. A.: Real-time estimation of $\mathrm{pH}$ and aragonite saturation state from Argo profiling floats: Prospects for an autonomous carbon observing strategy, Geophys. Res. Lett., 38, L17603, doi:10.1029/2011GL048580, 2011.

Key, R. M., Quay, P. D., Jones, G. A., McNichol, A. P., von Reden, K. F., and Schneider, R. J.: WOCE Radiocarbon I: Pacific Ocean Results; P6, P16, P17, Radiocarbon, 38, 425-518, 1996.

Key, R. M., Quay, P. D., Schlosser, P., McNichol, A.P., von Reden, K. F., Schneider, R. J., Elder, K. L., Stuiver, M., and Östlund H. G.: WOCE radiocarbon IV: Pacific Ocean results; P10, P13N, P14C, P18, P19 and S4P, Radiocarbon, 44, 239-392, 2002.

Key, R. M., Kozyr, A., Sabine, C. L., Lee, K., Wanninkhof, R., Bullister, J. L., Feely, R. A., Millero, F. J., Mordy, C., and Peng T.-H.: A global ocean carbon climatology: Results from Global Data Analysis Project (GLODAP), Global Biogeochem. Cy., 18, GB4031, doi:10.1029/2004GB002247, 2004.

Kim, T.-W., Lee, K., Feely, R. A., Sabine, C. L., Chen, C.-T. A., Jeong, H. J., and Kim, K. Y.: Prediction of Sea of Japan (East Sea) acidification over the past 40 years using a multiparameter regression model, Global Biogeochem. Cy., 24, GB3005, doi:10.1029/2009GB003637, 2010

Lamb, M. F., Sabine, C. L., Feely, R. A., Wanninkhof, R., Key, R. M., Johnson, G. C., Millero, F. J., Lee, K., Peng, T.-H., Kozyr, A., Bullister, J. L., Greeley, G., Byrne, R. H., Chipman, D. W., Dickson, A.G., Goyet, C., Guenther, P. R., Ishii, M., Johnson, K. M., Keeling, C. D., Ono, T., Shitashima, K., Tilbrook, B., Takahashi, T., Wallace, D. W. R., Watanabe, Y. W., Winn, C., and Wong, C. S.: Consistency and synthesis of Pacific Ocean $\mathrm{CO}_{2}$ survey data, Deep-Sea Res. II, 49, 21-58, 2002.

Lee, K., Wanninkhof, R., Feely, R. A., Millero, F. J., and Peng T. .H.: Global relationships of total inorganic carbon with temperature and nitrate in surface seawater, Global Biogeochem. Cy., 14, 979-994, doi:10.1029/1998GB001087, 2000. 
Lee, K., Tong, L. T., Millero, F. J., Sabine, C. L., Dickson, A. G., Goyet, C., Park, G. H., Wanninkhof, R., Feely, R. A., and Key, R. M.: Global relationships of total alkalinity with salinity and temperature in surface waters of the world's oceans, Geophys. Res. Lett., 33, L19605, doi:10.1029/2006GL027207, 2006.

Lewis, E. and Wallace, D. W. R.: Program developed for $\mathrm{CO}_{2}$ system calculations, Rep. 105, 33 pp., Oak Ridge Natl. Lab., Oak Ridge, Tenn., available at: http://cdiac.esd.ornl.gov/oceans/ co2rprt.html, 1998.

McCartney, M. S.: Subantarctic mode water, Deep-Sea Res., 24, 103-119, 1977.

McCartney, M. S.: The subtropical recirculation of Mode Waters, J. Mar. Res., 40, Suppl., 427-464, 1982.

McNeil, B. I.: Diagnosing coastal ocean $\mathrm{CO}_{2}$ interannual variability from a 40 year hydrographic time series station off the east coast of Australia, Global Biogeochem. Cy. 24, GB4034, doi:10.1029/2010GB003870, 2010.

McNeil, B. I. and Matear, R. J.: Southern Ocean acidification: A tipping point at $450-$ ppm atmospheric $\mathrm{CO}_{2}$, P. Natl. Acad. Sci. USA, 105, 18860-18864, 2008.

McNeil, B. I., Tilbrook, B., and Matear, R. J.: Accumulation and uptake of anthropogenic $\mathrm{CO}_{2}$ in the Southern Ocean, south of Australia between 1968 and 1996, J. Geophys. Res., 106, 3143131445, doi:10.1029/2000JC000331, 2001.

McNeil, B. I., Sweeney, C., and Gibson, J. A. E.: Natural seasonal variability of aragonite saturation state within two Antarctic coastal ocean sites, Antarctic Sci., 23, 411-412, doi10.1017/S0954102011000204, 2011.

Millero, F. J.: Thermodynamics of the carbon dioxide system in the Oceans, Geochim. Cosmochim. Ac., 59, 661-677, doi:10.1016/0016-7037(94)00354-O, 1995.

Millero, F. J., Lee, K., and Roche, M.: Distribution of alkalinity in the surface waters of the major oceans, Mar. Chem., 60, 111-130, 1998.

Mucci, A.: The solubility of calcite and aragonite in seawater at various salinities, temperatures and one atmosphere total pressure, Am. J. Sci., 283, 780-799, 1983.

Murata, A., Kumamoto, Y, Watanabe, S., and Fukasawa, M.: Decadal increases of anthropogenic $\mathrm{CO}_{2}$ in the South Pacific subtropical ocean along $32^{\circ} \mathrm{S}$, J. Geophys. Res., 112, C05033, doi:10.1029/2005JC003405, 2007.

Murata, A., Kumamoto, Y., Sasaki, K., Watanabe, S., and Fukasawa, M.: Decadal increases of anthropogenic $\mathrm{CO}_{2}$ in the subtropical South Atlantic Ocean along $30^{\circ} \mathrm{S}$, J. Geophys. Res., 113, C06007, doi:10.1029/2007JC004424, 2008.

Murata, A., Kumamoto, Y., Sasaki, K., Watanabe, S., and Fukasawa, M.: Decadal increases in anthropogenic $\mathrm{CO}_{2}$ along $20^{\circ} \mathrm{S}$ in the South Indian Ocean, J. Geophys. Res., 115, C12055, doi:10.1029/2010JC006250, 2010.

Orr, J. C., Fabry, V. J., Aumont, O., Bopp, L., Doney, S. C., Feely, R. A., Gnanadesikan, A., Gruber, N., Ishida, A., Joos, F., Key, R. M., Lindsay, K., Maier-Reimer, E., Matear, R., Monfray, P., Mouchet, A., Najjar, R. G., Plattner, G.-K., Rodgers, K. B., Sabine, C.L., Sarmiento, J. L., Schlitzer, R., Slater, R. D., Totterdell, I. J., Weirig, M.-F., Yamanaka, Y., and Yool, A.: Anthropogenic ocean acidification over the twenty-first century and its impact on calcifying organisms, Nature, 437, 681-686, 2005.

Orsi, A. H. and Whitworth III, T.: Hydrographic atlas of the world ocean circulation experiment (WOCE), in: Southern Ocean, vol.
1, International WOCE project Office, edited by: Sparrow, M., Chapman, P., and Gould, J., International WOCE Project Office Southampton, UK, ISBN 0-904175-49-9, 2005.

Pearson R. K.: Outliers in process modelling and identification, IEEE Trans. Control Syst. Tech., 10, 55-63, 2002.

Peng, T.-H. and Wanninkhof, R.: Increase in anthropogenic $\mathrm{CO}_{2}$ in the Atlantic Ocean in the last two decades, Deep Sea Res. I, 57, 755-770, 2010.

Peng, T.-H., Wanninkhof, R., and Feely, R. A.: Increase of anthropogenic $\mathrm{CO}_{2}$ in the Pacific Ocean over the last two decades, Deep Sea Res. II, 50, 3065-3082, 2003.

Ridgway K. R., Dunn, J. R., and Wilkin, J. L.: Ocean interpolation by four-dimensional least squares - Application to the waters around Australia, J. Atmos. Ocean. Tech., 19, 1357-1375, 2002.

Sabine, C. L., Key, R. M., Johnson, K. M., Millero, F. J., Poisson, A., Sarmiento, J. L., Wallace, W. R., and Winn, C. D.: Anthropogenic $\mathrm{CO}_{2}$ inventory of the Indian Ocean, Global Biogeochem. Cy., 13, 179-198, 1999.

Sabine, C. L., Feely, R. A., Gruber, N., Key, R. M., Lee, K., Bullister, J. L., Wanninkhof, R., Wong, C. S., Wallace, D. W. R., Tilbrook, B., Millero, F. J., Peng, T.-H., Kozyr, A., Onon, T., and Rios, A. F.: The Oceanic Sink for Anthropogenic $\mathrm{CO}_{2}$, Science, 305, 367-371, 2004.

Sabine, C. L., Feely, R. A., Millero, F. J., Dickson, A. G., Langdon, C., Mecking, S., and Greeley, D.: Decadal changes in Pacific carbon, J. Geophys. Res., 113, C07021, doi:10.1029/2007JC004577, 2008.

Sabine, C. L., Hoppema, M., Key, R. M., Tilbrook, B., van Heuven, S., Lo Monaco, C., Metzl, N., Ishii, M., Murata, A., and Musielewicz, S.: Assessing the internal consistency of the CARINA data base in the Pacific sector of the Southern Ocean, Earth Syst. Sci. Data, 2, 195-204, doi:10.5194/essd-2-195-2010, 2010.

Sallée, J.-.B., Speer, K., Rintoul, S., and Wijffels, S.: Southern Ocean thermocline ventilation, J. Phys. Ocean., 40, 509-529, 2010.

Sallée, J.-.B., Matear, R. J., Rintoul, S. R., and Lenton, A.: Localized subduction of anthropogenic carbon dioxide in the Southern Hemisphere oceans, Nat. Geosci., 5, 579-584, doi:10.1038/NGEO1523, 2012.

Sasse, T. P., McNeil, B. I., and Abramowitz, G.: A novel method for diagnosing seasonal to inter-annual surface ocean carbon dynamics from bottle data using neural networks, Biogeosciences, 10, 4319-4340, 2013, http://www.biogeosciences.net/10/4319/2013/.

Sloyan, B. M., Talley, L. D., Chereskin, T. K., Fine, R. A., and Holte, J.: Antarctic Intermediate Water and Subantarctic Mode Water formation in the Southeast Pacific: The role of turbulent mixing, J. Phys. Oceanogr., 40, 1558-1574, 2010.

Sokolov, S. and Rintoul, S. R.: Circulation and water masses of the southwest Pacific: WOCE section P11, Papua New Guinea to Tasmania, J. Mar. Res., 58, 223-268, 2000.

Sokolov, S. and Rintoul S. R.: Circumpolar structure and distribution of the Antarctic Circumpolar Current fronts: 1. Mean circumpolar paths, J. Geophys. Res., 114, C11018, doi:10.1029/2008JC005108, 2009.

Stramma, L. and England, M.: On the water masses and mean circulation of the South Atlantic Ocean, J. Geophys. Res., 104, 20863-20883, 1999. 
Talley, L. D.: Antarctic Intermediate Water in the South Atlantic, In: The South Atlantic: Present and past circulation, edited by: Wefer, G., Berger, W. H., Siedler, G., and Webb, D. J., Springer, New York, 219-238, 1996.

Talley, L. D.: Some aspects of ocean heat transport by the shallow, intermediate and deep overturning circulations, In: Mechanisms of Global Climate Change at Millennial Time Scales, edited by: Clark, P. U., Webb, R. S., and Keigwin, L. D., Geophys. Mono. Series 112, AGU, 1-22, 1999.

Tanhua, T., Olsen, A., Hoppema, M., Jutterström, S., Schirnick, C., van Heuven, S., Velo, A., Lin, X., Kozyr, A., Alvarez, M., Bakker, D. C. E., Brown, P., Falck, E., Jeansson, E., Lo Monaco, C., Olafsson, J., Perez, F. F., Pierrot, D., Rios, A. F., Sabine, C. L., Schuster, U., Steinfeldt, R., Stendardo, I., Anderson, L. G., Bates, N. R., Bellerby, R. G. J., Blindheim, J., Bullister, J. L., Gruber, N., Ishii, M., Johannessen, T., Jones, E. P., Köhler, J., Körtzinger, A., Metzl, N., Murata, A., Musielewicz, S., Omar, A. M., Olsson, K. A., de la Paz, M., Pfeil, B., Rey, F., Rhein, M., Skjelvan, I., Tilbrook, B., Wanninkhof, R., Mintrop, L., Wallace, D. W. R., and Key, R. M.: CARINA Data Synthesis Project. ORNL/CDIAC-157, NDP-091. Carbon Dioxide Information Analysis Center, Oak Ridge National Laboratory, US Department of Energy, Oak Ridge, Tennessee, doi:10.3334/CDIAC/otg.ndp091, 2008.
Tanhua, T., van Heuven, S., Key, R. M., Velo, A., Olsen, A., and Schirnick, C.: Quality control procedures and methods of the CARINA database, Earth Syst. Sci. Data, 2, 35-49, doi:10.5194/essd-2-35-2010, 2010.

Tomczak, M. and Godfrey, J. S.: Regional oceanography: an introduction, Pergamon Press, 1994.

Velo, A., Pérez, F. F., Tanhua, T., Gilcoto, M., Ríos, A. F., and Key, R. M.: Total alkalinity estimation using MLR and neural network techniques, J. Mar. Syst., 111-112, 11-18, 2013.

Wallace, D. W. R.: Monitoring global ocean carbon inventories, Ocean Observing System Development Panel, Texas A\&M University, College Station, TX, 54 pp., 1995.

Wanninkhof, R., Doney, S. C., Bullister, J. L., Levine, N. M., Warner, M., and Gruber, N.: Detecting anthropogenic $\mathrm{CO}_{2}$ changes in the interior Atlantic Ocean between 1989 and 2005, J. Geophys. Res., 115, C11028, doi:10.1029/2010JC006251, 2010.

Warren, B. A.: Deep circulation of the world ocean, In: Evolution of Physical Oceanography, edited by: Warren B. A. and Wunsch, C., MIT Press, Cambridge, 6-41, 1981.

WOA: World Ocean Atlas, available at: http://www.nodc.noaa.gov/ OC5/WOA09/pr_woa09.html, 2009. 